\title{
ASSESSMENT OF NUTRITIONAL STATUS AND NUTRITION IN PATIENTS WITH ARTERIAL HYPERTENSION
}

\author{
OCENA STANU ODŻYWIENIA I SPOSOBU ŻYWIENIA \\ PACJENTÓW Z NADCIŚNIENIEM TĘTNICZYM
}

Poznań University of Medical Sciences, Department of Gastroenterology, Dietetics and Internal Medicine Uniwersytet Medyczny w Poznaniu, Katedra i Klinika Gastroenterologii, Dietetyki i Chorób Wewnętrznych

\section{ABSTRACT}

INTRODUCTION. The factors predisposing to the occurrence of cardiovascular event are mainly age, visceral obesity and metabolic syndrome. To our knowledge, there are no studies assessing both the nutritional status and diet of hypertensive patients in Poland.

AIM. Our aim is the assessment of the diet and nutritional status of patients with hypertension.

MATERIAL AND METHODS. This study included 50 patients (K: 32, M: 18) with hypertension admitted to the Department of Internal Medicine at the Heliodor Święcicki Clinical Hospital in Poznan. Anthropometric measurements (waist and hip circumference), and body composition analysis were used to assess nutritional status. Additionally, we carried out the nutritional interview.

RESULTS. We observed that among hypertensive patients, overweight occurred in $18 \%$ and obesity (definition based on BMI) in $48 \%$ of all patients. We found that visceral obesity (definition based on WHR) concerns $76 \%$ of patients. Moreover, we diagnosed a metabolic syndrome in $56 \%$ of patients. None of the patients treated the DASH diet, especially recommended for the treatment of hypertension. What's more, as many as $50 \%$ of hypertensive patients used salt for meals twice a day.

CONCLUSIONS. In patients with hypertension the frequent occurrence of obesity and metabolic syndrome may to a large extent result from the dietary support deviating from the rational diet. There is a need to educate patients with arterial hypertension in the field of non-pharmacological treatment methods, especially diet therapy

Key words: hypertension, nutritional status, assessment of the diet

\section{STRESZCZENIE}

WPROWADZENIE. Do czynników predysponujących do wystąpienia nadciśnienia tętniczego należy głównie wiek, otyłość androidalna i współwystępujące zaburzenia metaboliczne oraz styl życia, w tym szczególnie nieprawidłowy sposób żywienia, siedzący tryb życia i palenie tytoniu. Dotychczas przeprowadzone badania naukowe oceniające zarówno stan odżywienia, jak i sposób żywienia pacjentów z nadciśnieniem tętniczym w Polsce uzasadniają potrzebę dalszych badań w tym obszarze.

CEL. Celem naszej pracy jest ocena sposobu żywienia i stanu odżywienia pacjentów z nadciśnieniem tętniczym. MATERIAL I METODY. Do badania naukowego włączono 50 pacjentów (K:32, M:18) z nadciśnieniem tętniczym, pozostających pod opieką Oddziału Chorób Wewnętrznych Szpitala Klinicznego im. Heliodora Święcickiego w Poznaniu. Do oceny stanu odżywienia wykorzystano pomiary antropometryczne (obwód talii i bioder) oraz analizę składu ciała. Ocena sposobu żywienia metodą częstotliwości spożycia została przeprowadzona w oparciu o autorski wywiad żywieniowy.

WYNIKI. Wśród pacjentów z nadciśnieniem tętniczym nadwaga występowała u 18\%, a otyłość ogólnie u 48\% badanych osób. Otyłość androidalną rozpoznawaną na podstawie WHR stwierdzono u aż 76\% badanych, a u 56\% respondentów stwierdzono zespół metaboliczny. Żaden z pacjentów nie stosował leczenia dietetycznego dietą DASH, zalecaną szczególnie w terapii nadciśnienia tętniczego. 50\% pacjentów z nadciśnieniem tętniczym dwa razy dziennie używało soli kuchennej do przyprawiania posiłków. 
WNIOSKI. Częste występowanie wśród pacjentów z nadciśnieniem tętniczym otyłości ogólnie i zespołu metabolicznego w dużej mierze może wynikać ze sposobu żywienia odbiegającego od racjonalnej diety, np. diety DASH. Istnieje potrzeba edukacji pacjentów z nadciśnieniem tętniczym krwi w zakresie niefarmakologicznych metod leczenia, w tym szczególnie dietoterapii.

Slowa kluczowe: nadciśnienie tętnicze, stan odżywienia, sposób żywienia

\section{INTRODUCTION}

Hypertension increases the risk of cardiovascular disease (coronary artery disease, stroke, peripheral arterial disease, heart failure) and renal failure, regardless of age or gender. Therefore is a significant risk factor for premature death. Visceral obesity and co-occurring metabolic disorders are factors that predispose to the development of arterial hypertension. The Polish Society of Hypertension emphasizes the important role of non-pharmacological treatment, including dietotherapy-especially DASH diet (Dietary Approaches to Stop Hypertension) or Mediterranean diet $(1,2)$. The our aim is the assessment of nutritional status and nutrition of patients with arterial hypertension. In this study we evaluated the frequency of metabolic syndrome and visceral obesity, the frequency of using the DASH diet, and the relationship between diet and nutritional status in patients with arterial hypertension.

\section{MATERIALS AND METHODS}

We assessed the 50 patients (within 6 months, 2018) with arterial hypertension in age 28-78 years admitted to the Department of Gastroenterology, Dietetics and Internal Medicine. To the assessment of nutrition we used own nutritional questionnaire (during the 45-minute dietary consultation). The nutritional interview included questions about the DASH diet (Have you ever used the DASH diet?, Do you know the rules of the DASH diet?) and questions about the frequency of consumption of individual food products, such as vegetables and fruits, seeds and nuts, dairy, grain and meat products and sweets (Tab. III, IV). Additionally we asked the respondents about intake of fast-food, alcohol and salt. On the basis of a general medical interview, we obtained information on comorbidites (with hypertension) and metabolic disorders, where also included laboratory tests (e.g. fasting glucose). We defined nutritional status using the body mass index-BMI (3). The nutritional status we assessed with the use of anthropometric measurements (waist and hip circumference) made with a measure for measuring body circumferences (Seca-201) and body composition analysis performed with a professional body composition analyzer (TANITA MC-980). The body composition analyzer uses the

\section{WSTEP}

Nadciśnienie tętnicze krwi zwiększa ryzyko wystąpienia chorób układu krążenia (choroby wieńcowej, udaru mózgu, choroby tętnic obwodowych, niewydolności serca) i niewydolności nerek, niezależnie od wieku czy płci, tym samym stanowi istotny czynnik ryzyka przedwczesnych zgonów. Otyłość wisceralna i współwystępujące zaburzenia metaboliczne to czynniki predysponujące do wystąpienia nadciśnienia tętniczego krwi. Polskie Towarzystwo Nadciśnienia Tętniczego podkreśla istotną rolę leczenia niefarmakologicznego, w tym dietoterapii opierającej się o model diety DASH (Dietary Approaches to Stop Hypertension) lub śródziemnomorskiej $(1,2)$. Cel główny naszej pracy to ocena stanu odżywienia i sposobu żywienia pacjentów z nadciśnieniem tętniczym. W niniejszej pracy badawczej podjęto próbę scharakteryzowania (uwzględniając stan odżywienia i sposób żywienia) 50 pacjentów z nadciśnieniem tętniczym krwi. Wyznaczono cele szczegółowe, w których oceniono: częstość występowania zespołu metabolicznego i otyłości wisceralnej, częstość stosowania diety DASH oraz zależność między sposobem żywienia a stanem odżywienia pacjentów z nadciśnieniem tętniczym krwi.

\section{MATERIAŁ I METODY}

Ocenie stanu odżywienia i sposobu żywienia poddano 50 pacjentów (K:32, M:18) w wieku 28-78 lat (średnia wieku $59 \pm 12$ lat) z rozpoznanym nadciśnieniem tętniczym pozostających pod opieką Katedry i Kliniki Gastroenterologii, Dietetyki i Chorób Wewnętrznych Szpitala Klinicznego im. Heliodora Święcickiego w Poznaniu. Sposób żywienia oceniano $\mathrm{z}$ wykorzystaniem autorskiego kwestionariusza żywieniowego. Grupę badaną do niniejszej pracy badawczej zebrano w ciągu sześciu miesięcy (2018r.). Zarówno ocenę stanu odżywienia jak i ocenę sposobu żywienia wykonano podczas wizyty dietetyka (ok. 45 minutowej) na Oddziale Gastroenterologii, Dietetyki i Chorób Wewnętrznych. W kwestionariuszu żywieniowym uwzględniono pytania dotyczące diety DASH (Czy kiedykolwiek stosowano dietę DASH?, Czy znane sa zasady diety DASH?) oraz pytania dotyczące częstotliwości spożycia poszczególnych produktów żywnościowych takich jak warzywa i owoce, nasiona i orzechy, produkty mleczne, zbożowe i mięsne oraz 
bioelectricalimpedance analysis method (BIA), i.e. the electrical resistance of the body's tissues after passing a low current. Based on body composition analysis we assessed the frequency of increased visceral fat index ( $\geq 12)$. Furthermore, we evaluated the frequency of the metabolic syndrome, which was diagnosed on the basis of the definition of NCEP-ATP III (National Cholesterol Education Program-Adult Treatment Panel III) (4). In this study, we also checked the frequency of visceral obesity diagnosed according to two definitions, i.e. on the basis of the WHR (Waist to Hip Ratio) in men $\geq 1$, in women $\geq 0,8$ and on the basis of the waist circumference (in the European population) in men $>94 \mathrm{~cm}$, women $>80 \mathrm{~cm}$. The statistical analysis we performed using the STATISTICA (Data Analysis Software System) version 12.0 software by StatSoft, Inc. (2014) (www.statsoft.com). The results we presented as the number (n) and percentage (\%). The analysis of the relationship between the examined categorical variables we performed using the Fisher's exact test or the Chi-square test. The results we considered significant for $\mathrm{p}<0,05$.

\section{RESULTS}

\section{The assessment of nutritional status}

Based on the BMI assessment, we found overweight in $18 \%$ of respondents $(\mathrm{n}=9)$, and general obesity in $48 \%(n=24)$, including grade III obesity in $20 \%$ of the patients (3).We observed showed that overweight was more common in women than in men $(19 \%$ vs. $17 \%$, respectively), and obesity was more frequent in men than in women ( $50 \%$ vs. $47 \%$, respectively). Visceral obesity diagnosed on the basis of waist circumference we noted in $66 \%$ of patients (Tab.II). The frequency of diseases and metabolic disorders comorbid with arterial hypertension (i.e. type 2 or other diabetes, carbohydrate metabolism disorders, hypercholesterolaemia, mixed hyperlipidaemia, triglyceridaemia, or lipid metabolism disorders) among the respondents shows table I (Tab.I). We found metabolic syndrome in more than half of the patients with arterial hypertension. Moreover we noted increased content of visceral fat in as many as $30 \%$ of the respondents.

\section{The assessment of nutrition}

In this study, none of the respondents used the DASH dietary treatment and showed no knowledge of the rules of this diet $(100 \%)$. On the basis on the frequency of consumption of especially food groups during the day or week (from the nutritional interview), we checked to what extent the patients were able to meet some of the DASH diet guidelines through their usual nutrition (according to the authors of this research, a model similar to the DASH diet is two of the słodycze (Tab.III, IV). Dodatkowo respondentów pytano także o spożywanie dań typu fast-food, alkoholu oraz soli spożywczej. Na podstawie wywiadu ogólnolekarskiego uzyskano informacje dotyczące współwystępujących (z nadciśnieniem tętniczym krwi) chorób i zaburzeń metabolicznych, gdzie uwzględniono także badania laboratoryjne (np. stężenie glukozy na czczo). Stan odżywienia definiowano przy użyciu indeksu masy ciała BMI (ang. Body Mass Index) (3). Do oceny stanu odżywienia wykorzystano pomiary antropometryczne (obwód talii i bioder) wykonane miarą do mierzenia obwodów ciała (Seca-201) oraz analizę składu ciała wykonaną przy użyciu profesjonalnego analizatora składu ciała (TANITA MC-980). Analizator składu ciała wykorzystuje metodę bioimpedancji elektrycznej (ang. bioelectrical impedance analysis, $B I A)$ tj. oporu elektrycznego tkanek organizmu po przepuszczeniu prądu o niskim natężeniu. Na podstawie analizy składu ciała oceniono częstość występowania podwyższonego wskaźnika tłuszczu trzewnego $(\geq 12)$. Dodatkowo wśród respondentów oceniono częstość występowania zespołu metabolicznego, który rozpoznawano na podstawie definicji NCEP-ATP III (ang. National Cholesterol Education Program-Adult Treatment Panel III) (4). W niniejszej pracy badawczej sprawdzono także częstość występowania otyłości wisceralnej rozpoznawanej według dwóch definicji tj. na podstawie wskaźnika WHR (ang. Waist to Hip Ratio) u mężczyzn $\geq 1$, u kobiet $\geq 0,8$ oraz na podstawie obwodu talii (w populacji europejskiej) u mężczyzn $>94 \mathrm{~cm}$, u kobiet $>80 \mathrm{~cm}$. Analizę statystyczną wykonano w programie STATISTICA (Data Analysis Software System) version 12.0, firmy StatSoft, Inc. (2014) (www.statsoft.com). Wyniki przedstawiono za pomocą liczebności (n) oraz wartości procentowej (\%). Analizę zależności między badanymi zmiennymi kategorialnymi przeprowadzono przy użyciu dokładnego testu Fisher'a lub testu Chi-kwadrat. Wyniki uznano za istotne dla $\mathrm{p}<0,05$.

\section{WYNIKI}

\section{Ocena stanu odżywienia}

Na podstawie oceny indeksu masy ciała BMI nadwagę stwierdzono u $18 \%$ respondentów $(\mathrm{n}=9)$, a otyłość ogólnie u 48\% (n=24), w tym otyłość III stopnia rozpoznano u $20 \%$ badanych osób (3). Nadwaga dotyczyła częściej kobiet niż mężczyzn (19\% vs. 17\%, odpowiednio), a otyłość ogólnie częściej mężczyzn niż kobiet (50\% vs. $47 \%$, odpowiednio). Otyłość wisceralna rozpoznawana na podstawie obwodu talii występowała u 66\% pacjentów (Tab.II). Częstość występowania wśród osób badanych chorób i zaburzeń metabolicznych współwystępujących z nadciśnieniem tętniczym krwi (tj. cukrzycy typu 2 lub innej, 
Table I. The frequency of selected comorbid diseases in the studied group with arterial hypertension.

Tabela I. Częstość występowania wybranych jednostek chorobowych u badanych osób z nadciśnieniem tętniczym

\begin{tabular}{|c|c|c|}
\hline Cukrzyca typu 2 lub inna & $\mathbf{n}$ & $\mathbf{\%}$ \\
\hline $\mathrm{T}^{*}$ & 20 & 40 \\
\hline $\mathrm{N}^{*}$ & 30 & 60 \\
\hline $\begin{array}{c}\text { Zaburzenia przemiany } \\
\text { węglowodanów }\end{array}$ & $\mathbf{n}$ & $\mathbf{\%}$ \\
\hline $\mathrm{T}$ & 5 & 10 \\
\hline $\mathrm{N}$ & 45 & 90 \\
\hline $\begin{array}{c}\text { Hipercholesterolemia/ } \\
\text { hiperlipidemia mieszana/ } \\
\text { Hipertrójglicerydemia }\end{array}$ & $\mathbf{n}$ & $\mathbf{\%}$ \\
\hline $\mathrm{T}$ & 20 & 40 \\
\hline $\mathrm{N}$ & 30 & 60 \\
\hline
\end{tabular}

* „T” oznacza „tak” czyli występowanie danej jednostki chorobowej, ,N” oznacza „nie”.

four criteria for a rational diet: eating vegetables and fruit 4-5 times a day, eating dairy products 2-3 times a day, eating fish 2-4 times a week, eating nuts and seeds 4-5 times a week). Detailed results for selected elements of the DASH diet model show tables III and IV (Tab.III, IV). Based on the results obtained in this study, we observed that less than $1 / 3$ of the study group consumed vegetables three times a day. We noted that $70 \%$ of the patients intook dairy products daily. Over $60 \%$ of the respondents did not eat any nuts or seeds. The sweets more than three times a week consumed $38 \%$ of the patients.

\section{The nutritional status and nutrition}

In the group of patients with BMI $<25 \mathrm{~kg} / \mathrm{m}^{2}(\mathrm{n}=17)$ $35 \%$ of respondents $(n=6)$ used a diet similar to the DASH model, and the remaining $65 \%(\mathrm{n}=11)$ negated the use of this nutritional standard. However, in the group of patients with BMI $>25 \mathrm{~kg} / \mathrm{m}^{2}(\mathrm{n}=33) 24 \%$ of respondents $(\mathrm{n}=8)$ followed a diet similar to the DASH diet, and $76 \%$ of the respondents $(n=25)$ did not use this model of nutrition. We did not find correlation between the use of a diet similar to the DASH model and BMI $(\mathrm{p}=0,3076)$. Patients with arterial hypertension $(\mathrm{AH})$ and $\mathrm{BMI}<25 \mathrm{~kg} / \mathrm{m}^{2}$ do not use the DASH-like nutritional model more often than patients with $\mathrm{AH}$, but BMI $>25 \mathrm{~kg} / \mathrm{m}^{2}$. We did not show statistically significant correlation between the frequency of consumption of sweets $(p=0,2054)$ and alcohol $(p=$ 0,1228 ) and the index of visceral fat. On the other hand, we found that patients with a visceral fat index $<12$ eat fast food more frequent than patients with a visceral fat index $\geq 12(p=0,0404)$. We did not find statistically significant correlation between the frequency of fruit consumption per day and fasting glucose.
Table II. The frequency of visceral obesity in the studied group

Tabela II. Częstość występowania otyłości wisceralnej w badanej grupie

\begin{tabular}{|c|c|c|}
\hline Otyłość androidalna (WHR) & $\mathbf{n}$ & $\mathbf{\%}$ \\
\hline $\mathrm{T}^{*}$ & 38 & 76 \\
\hline $\mathrm{N}^{*}$ & 12 & 24 \\
\hline $\begin{array}{c}\text { Otyłość androidalna } \\
\text { (obwód talii) }\end{array}$ & $\mathbf{n}$ & $\mathbf{\%}$ \\
\hline $\mathrm{T}$ & 33 & 66 \\
\hline $\mathrm{N}$ & 17 & 34 \\
\hline
\end{tabular}

* „T” oznacza ,tak” czyli występowanie otyłości rozpoznawanej na podstawie WHR i obwodu talii, „N” oznacza ,nie”.

zaburzeń przemian węglowodanów, hipercholesterolemii, hiperlipidemii mieszanej, trójglicerydemii, czy zaburzeń przemian lipidów) przedstawiono w tabeli I (Tab.I). Zespół metaboliczny stwierdzono u ponad połowy pacjentów $\mathrm{z}$ nadciśnieniem tętniczym krwi. Aż 30\% badanych osób charakteryzowało się zwiększoną zawartością tkanki tłuszczowej wewnętrznej.

\section{Ocena sposobu żywienia}

$\mathrm{W}$ badanej grupie żaden $\mathrm{z}$ respondentów nie stosował leczenia dietetycznego DASH i nie wykazywał także znajomości zasad tej diety $(100 \%)$. Na podstawie częstotliwości spożycia poszczególnych grup produktów żywnościowych w ciągu dnia lub tygodnia (z wywiadu żywieniowego) sprawdzono, w jakim stopniu poprzez zwyczajowe żywienie pacjenci są w stanie spełnić niektóre z wytycznych diety DASH (wg autorów pracy model zbliżony do diety DASH to spełnienie $\mathrm{m}$. in. dwóch z czterech wymienionych kryteriów racjonalnej diety: spożywanie warzyw i owoców 4-5 razy dziennie, spożywanie produktów mlecznych 2-3 razy dziennie, spożywanie ryb 2-4 razy tygodniowo, spożywanie orzechów i nasion 4-5 razy tygodniowo). Szczegółowe wyniki dla wybranych elementów modelu diety DASH przedstawiono w tabelach III i IV (Tab.III, IV). Na podstawie wyników uzyskanych w badaniu zaobserwowano, że mniej niż 1/3 grupy badanej spożywała trzy razy dziennie warzywa. Produkty mleczne spożywało codziennie $70 \%$ badanych pacjentów. Ponad $60 \%$ respondentów nie spożywało żadnych orzechów i nasion. Słodycze częściej niż trzy razy w tygodniu jadło $38 \%$ badanych pacjentów.

\section{Sposób żywienia a stan odżywienia}

$\mathrm{W}$ grupie osób badanych $\mathrm{z}$ BMI $<25 \mathrm{~kg} / \mathrm{m}^{2} \quad(\mathrm{n}=17)$ $35 \%$ respondentów $(\mathrm{n}=6)$ stosowało dietę zbliżoną do modelu DASH, a pozostałe $65 \%(\mathrm{n}=11)$ negowało stosowanie tego standardu żywieniowego. Natomiast w grupie osób z BMI $>25 \mathrm{~kg} / \mathrm{m}^{2}$ ( $\mathrm{n}=33$ ) $24 \%$ respon- 
Table III. The frequency of consumption of individual groups of DASH diet products/day

Tabela III. Częstotliwość spożycia poszczególnych grup produktów diety DASH/dzień

\begin{tabular}{|c|c|c|}
\hline $\begin{array}{c}\text { Częstotliwość spożycia } \\
\text { poszczególnych grup } \\
\text { produktów spożywczych/dobę* }\end{array}$ & $\mathbf{n}$ & $\%$ \\
\hline \multicolumn{3}{|c|}{ Warzywa ogólnie } \\
\hline 0 & 3 & 6 \\
\hline 1 & 6 & 12 \\
\hline 2 & 29 & 58 \\
\hline 3 & 12 & 24 \\
\hline \multicolumn{3}{|c|}{ Surowe warzywa } \\
\hline 0 & 20 & 40 \\
\hline 1 & 19 & 38 \\
\hline 2 & 11 & 22 \\
\hline \multicolumn{3}{|c|}{ Owoce ogólnie } \\
\hline 0 & 10 & 20 \\
\hline 1 & 30 & 60 \\
\hline 2 & 10 & 20 \\
\hline \multicolumn{3}{|c|}{ Owoce surowe } \\
\hline 0 & 14 & 28 \\
\hline 1 & 26 & 52 \\
\hline 2 & 10 & 20 \\
\hline \multicolumn{3}{|c|}{ Produkty mleczne } \\
\hline 0 & 15 & 30 \\
\hline 1 & 28 & 56 \\
\hline $2-3$ & 7 & 14 \\
\hline \multicolumn{3}{|c|}{ Produkty mięsne } \\
\hline 0 & 5 & 10 \\
\hline $1-2$ & 38 & 76 \\
\hline 3 & 7 & 14 \\
\hline \multicolumn{3}{|c|}{ Produkty zbożowe } \\
\hline 0 & 0 & 0 \\
\hline $1-4$ & 50 & 100 \\
\hline \multicolumn{3}{|c|}{ Napoje ogólnie } \\
\hline $2-4$ & 7 & 14 \\
\hline $5-7$ & 15 & 30 \\
\hline $8-10$ & 28 & 56 \\
\hline \multicolumn{3}{|c|}{ W tym: woda mineralna } \\
\hline 0 & 5 & 10 \\
\hline 2 & 17 & 34 \\
\hline 4 & 14 & 28 \\
\hline 8 & 14 & 28 \\
\hline \multicolumn{3}{|c|}{ napoje słodkie } \\
\hline 0 & 39 & 78 \\
\hline 1 & 11 & 22 \\
\hline
\end{tabular}

* Cyfry w pierwszej kolumnie odpowiadają liczbie posiłków w ciągu dnia, w których uwzględniono dany produkt spożywczy.
Table IV. The frequency of consumption of individual groups of DASH diet products/week

Tabela IV. Częstotliwość spożycia poszczególnych grup produktów diety DASH/tydzień

\begin{tabular}{|c|c|c|}
\hline $\begin{array}{c}\text { Częstotliwość spożycia } \\
\text { poszczególnych grup } \\
\text { produktów spożywczych/ } \\
\text { tydzień* }\end{array}$ & $\mathbf{n}$ & $\%$ \\
\hline \multicolumn{3}{|c|}{ Orzechy i nasiona } \\
\hline 0 & 32 & 64 \\
\hline 3 & 11 & 22 \\
\hline $4-5$ & 7 & 14 \\
\hline \multicolumn{3}{|c|}{ Ryby } \\
\hline 0 & 7 & 14 \\
\hline 1 & 28 & 56 \\
\hline $2-4$ & 15 & 30 \\
\hline \multicolumn{3}{|c|}{ Słodycze } \\
\hline $0-2$ & 32 & 64 \\
\hline$\geq 3$ & 18 & 36 \\
\hline
\end{tabular}

* Cyfry w pierwszej kolumnie odpowiadają liczbie posiłków w ciągu tygodnia, w których uwzględniono dany produkt spożywczy.

dentów $(\mathrm{n}=8)$ przestrzegało diety zbliżonej do diety DASH, a $76 \%$ osób badanych $(\mathrm{n}=25)$ nie stosowało tego modelu żywienia. Nie wykazano zależności między stosowaniem diety zbliżonej do modelu DASH a BMI $(\mathrm{p}=0,3076)$. Pacjenci $\mathrm{z}$ nadciśnieniem tętniczym krwi (NT) i BMI $<25 \mathrm{~kg} / \mathrm{m}^{2}$ nie stosują modelu żywieniowego zbliżonego do DASH częściej niż pacjenci z NT, ale BMI $>25 \mathrm{~kg} / \mathrm{m}^{2}$. Nie wykazano zależności istotnej statystycznie między modelem żywieniowym zbliżonym do DASH a występowaniem zespołu metabolicznego. Nie wykazano także istotnej statystycznie zależności między częstotliwością spożycia słodyczy $(p=0,2054)$ i alkoholu $(p=0,1228)$ a wskaźnikiem tłuszczu trzewnego. Z kolei wykazano, że pacjenci ze wskaźnikiem tłuszczu wewnętrznego $<12$ spożywają fast-food znacznie częściej niż pacjenci ze wskaźnikiem tłuszczu trzewnego $\geq 12(p=0,0404)$. Nie wykazano również istotnie statystycznej zależności między częstotliwością spożycia owoców na dobę a glikemią na czczo, natomiast wykazano, że u pacjentów spożywających więcej słodyczy na tydzień występował podwyższony poziom glukozy w surowicy krwi na czczo $(\mathrm{p}=0,0180)$. Sprawdzono także częstotliwość spożycia wody na dobę. Wykazano, że pacjenci o $B M I \geq 25 \mathrm{~kg} /$ $\mathrm{m}^{2}$ spożywają dwa litry wody znacznie częściej niż pacjenci o $B M I<25 \mathrm{~kg} / \mathrm{m}^{2}(\mathrm{p}=0,0118)$.

\section{DYSKUSJA}

W badanej grupie otyłość ogólnie występowała u blisko $50 \%$ pacjentów. $Z$ tym, że na podstawie ob- 
Nevertheless, we found that patients who consumed more sweets per week showed an increased level of fasting serum glucose $(p=0,0180)$. Additionally, we checked the daily frequency of water consumption and we exhibited that patients with $\mathrm{BMI} \geq 25 \mathrm{~kg} / \mathrm{m}^{2}$ consume two liters of water more commonly than patients with $\mathrm{BMI}<25 \mathrm{~kg} / \mathrm{m}^{2}(\mathrm{p}=0,0118)$.

\section{DISCUSSION}

General obesity in the studied group we found in nearly $50 \%$ of patients. However, on the basis of waist circumference (definition according to IDF, International Diabetes Federation), we diagnosed visceral obesity more commonly among respondents compared to general obesity $(66 \%$ vs. $48 \%$, respectively). We obtained similar results when the visceral obesity we diagnosed on the basis of the index WHR ( $76 \%$ vs. $48 \%$, respectively). Kucharska et al. assessing the nutritional status of respondents with arterial hypertension $(n=41)$ noted obesity in $58.5 \%$ of respondents, and visceral obesity in as much as $90 \%$ women and $95 \%$ of men (5). Skop-Lewandowska et al., assessing the prevalence of overweight and obesity among the elderly with cardiovascular diseases $(\mathrm{n}=128)$ found overweight in $33.8 \%$ of women and $50 \%$ of men, while general obesity in $27.7 \%$ of women and $17.7 \%$ of men (6). On the other hand, in the studied group, we found overweight in $19 \%$ of women and $17 \%$ of men, and general obesity we observed in $47 \%$ of women and $50 \%$ of men. Moreover, we found grade III obesity in as much as $19 \%$ of women and $22 \%$ of men. Jarosz et al. evaluating the diet and lifestyle of patients treated pharmacologically for arterial hypertension $(n=280)$, found general obesity in $71 \%$ of the respondents, and grade III obesity in $18 \%$ of the patients (7). Regulska-Ilow et al. when assessing the nutritional status and atherogeneity of the diet of the inhabitants of Wrocław ( $\mathrm{n}=1520$, over $60 \%$ of respondents with $\mathrm{AH})$ observed a higher BMI index among men more than women ( 27,3 vs. $\left.26,1 \mathrm{~kg} / \mathrm{m}^{2}, \mathrm{p}<0,0001\right)$. Based on anthropometric studies, Regulska-Ilow et al. showed overweight in $49.5 \%$ of men and $33.4 \%$ of women, and obesity in $19.8 \%$ of men and $17.8 \%$ of women (8). Janssen et al. determined that visceral obesity on the basis of waist circumference more often correlates with AH than abnormal BMI (9). In turn, in our study we observed that both $\mathrm{BMI} \geq 25 \mathrm{~kg} / \mathrm{m}^{2}$ and visceral obesity diagnosed on the basis of waist circumference (in the European population) concerned $66 \%$ of respondents, while visceral obesity defined on the basis of WHR (in the same study group) occurred in $76 \%$ of patients. Skop-Lewandowska et al. among all respondents with BMI $>30 \mathrm{~kg} / \mathrm{m}^{2}$ found visceral obesity based on WHR (10). However, in our study, in all patients wodu talii (definicja wg IDF, ang. International Diabetes Federation) znacznie częściej wśród respondentów rozpoznawano otyłość wisceralną w porównaniu do otyłości ogólnie ( $66 \%$ vs. $48 \%$, odpowiednio), podobne wyniki uzyskano stwierdzając otyłość wisceralną na podstawie wskaźnika WHR $(76 \%$ vs. $48 \%$, odpowiednio). Kucharska i wsp. oceniając stan odżywienia respondentów z nadciśnieniem tętniczym krwi $(\mathrm{n}=41)$ odnotowali, że otyłość ogólnie występowała u 58,5\% badanych osób, a otyłość wisceralna aż u 90\% kobiet i 95\% mężczyzn (5). Skop-Lewandowska i wsp. oceniając rozpowszechnienie nadwagi i otyłości wśród osób starszych z chorobami układu sercowo-naczyniowego $(n=128)$ stwierdzili nadwagę u 33,8\% kobiet i 50\% mężczyzn, z kolei otyłość ogólnie u 27,7\% kobiet i 17,7\% mężczyzn (6). Natomiast w badanej przez nas grupie nadwaga występowała u 19\% kobiet i 17\% mężczyzn, a otyłość ogólnie u 47\% kobiet i 50\% mężczyzn. Co więcej otyłość III stopnia dotyczyła aż 19\% kobiet i $22 \%$ mężczyzn. W badaniu naukowym $J a$ rosza i wsp. oceniającym sposób żywienia i styl życia pacjentów leczonych farmakologicznie $\mathrm{z}$ powodu nadciśnienia tętniczego krwi $(\mathrm{n}=280)$ otyłość ogólnie występowała u 71\% osób badanych, a otyłość III stopnia u $18 \%$ badanej populacji (7). Regulska-Ilow i wsp. oceniając stan odżywienia i aterogenność diety mieszkańców Wrocławia $(\mathrm{n}=1520$, ponad $60 \%$ osób badanych z NT) zaobserwowali, że wyższy wskaźnik BMI częściej dotyczy mężczyzn niż kobiet (27,3 vs. 26,1 $\left.\mathrm{kg} / \mathrm{m}^{2}, \mathrm{p}<0,0001\right)$. Na podstawie badań antropometrycznych Regulska-Ilow i wsp. nadwagę stwierdzili u 49,5\% mężczyzn i 33,4\% kobiet, a otyłość u 19,8\% mężczyzn i 17,8\% kobiet (8). Według Janssen i wsp. otyłość wisceralna stwierdzana na podstawie obwodu talii, częściej koreluje z NT niż nieprawidłowa wartość wskaźnika masy ciała BMI (9). Z kolei w przedstawionym badaniu zaobserwowano, że zarówno $\mathrm{BMI} \geq 25 \mathrm{~kg} /$ $\mathrm{m}^{2}$ jak i otyłość wisceralna rozpoznawana na podstawie obwodu talii (w populacji europejskiej) dotyczyła $66 \%$ respondentów, natomiast otyłość wisceralna definiowana na podstawie WHR (w tej samej grupie badanej) występowała aż u 76\% pacjentów. Skop-Lewandowska i wsp. oceniając stan odżywienia pacjentów z rozpoznanymi chorobami układu sercowo-naczyniowego $(n=156)$ zauważyli, że wśród wszystkich respondentów z BMI $>30 \mathrm{~kg} / \mathrm{m}^{2}$ występowała otyłość wisceralna stwierdzana na podstawie WHR (10). Natomiast $\mathrm{w}$ badanej przez nas grupie u wszystkich pacjentów z BMI $>30 \mathrm{~kg} / \mathrm{m}^{2}$ występował tylko zwiększony obwód talii, z kolei podwyższony wskaźnik WHR u 95\% badanych osób, co może wskazywać, że WHR ( $\geq 1$ u mężczyzn, $\geq 0,8$ u kobiet) częściej koreluje z NT niż obwód talii ( $>94 \mathrm{~cm}$ u mężczyzn, $>80 \mathrm{~cm}$ u kobiet) czy BMI $\left(\geq 25 \mathrm{~kg} / \mathrm{m}^{2}\right)$. 
with $\mathrm{BMI}>30 \mathrm{~kg} / \mathrm{m}^{2}$, we noted only increased waist circumference. The increased WHR we observed in $95 \%$ of the patients. Our results suggest that WHR $(\geq 1$ in men, $\geq 0,8$ in women) more often correlates with $\mathrm{AH}$ than waist circumference $(>94 \mathrm{~cm}$ in $\mathrm{men},>80 \mathrm{~cm}$ in women) or BMI $\left(\geq 25 \mathrm{~kg} / \mathrm{m}^{2}\right)$.

Lakowska et al. (2005), assessing the prevalence of the metabolic syndrome (MS) among patients with arterial hypertension $(n=572)$, found MS in $40.5 \%$ of the respondents on the basis of the definition of ATP III, while in this study we diagnosed MS (based on the definition of ATP III) in $56 \%$ of respondents (2018). It is worth noting that, according to the NCEPATP III definition, central obesity is not a necessary criteria for the diagnosis of MS (11). To our knowledge in the available medical literature (2005-2018) no other scientific publication assessing the prevalence of metabolic syndrome among patients with arterial hypertension in Poland. The metabolic syndrome is a group of disease entities that reach the scale of a global epidemic in the 21st century, and also pose an increased risk of cardiovascular diseases, which are the main cause of death in the world. The arterial hypertension despite extensive medical knowledge in this field is significant a health problem.

To our knowledge are also few scientific publications in the available medical literature regarding the dissemination of the DASH diet among patients with arterial hypertension. In our study group $(n=50)$, none of the respondents used the DASH diet treatment, moreover, none of the respondents showed knowledge of diet. Gajewska et al. obtained similar results assessing the knowledge and compliance with dietary recommendations by patients with arterial hypertension $(\mathrm{n}=86)$. Gajewska et al. noted that none of the respondents used the DASH dietary treatment, and only $15 \%$ of the respondents indicated some dietary modification (12). Silaste et al., when assessing the diet of patients with arterial hypertension treated pharmacologically $(n=716)$ did not find statistically significant differences between the diet of hypertensive patients compared to the control group (respondents not suffering from hypertension). Nonetheless, in both groups, the consumption of fat, saturated fatty acids, carbohydrates and dietary fibre did not meet the general dietary recommendations (13). In the WOBASZ II project assessing the eating habits of the Polish population aged over $20(n=5690)$ in the context of the prevention of cardiovascular diseases obtained similar results. Researchers of this project (WOBASZ II) found that the consumption of saturated and unsaturated fatty acids and dietary fibre differed from the patterns of rational nutrition. Additionally they observed that half of the studied population did not eats the recommended portion of vegetables and fruit (14).
Lakowska i wsp. (2005 rok) oceniając rozpowszechnienie zespołu metabolicznego $(\mathrm{ZM})$ wśród pacjentów z nadciśnieniem tętniczym krwi $(\mathrm{n}=572)$ na podstawie definicji ATP III stwierdzili ZM u 40,5\% badanych osób, natomiast w przedstawionym badaniu ZM także na podstawie definicji ATP III rozpoznano u 56\% respondentów (2018 rok). Warto zaznaczyć, że według definicji NCEP-ATP III otyłość centralna nie jest warunkiem niezbędnym do stwierdzenia ZM (11). W dostępnej literaturze medycznej (2005-2018) nie znaleziono innej publikacji naukowej dotyczącej rozpowszechnienia zespołu metabolicznego wśród pacjentów z nadciśnieniem tętniczym w Polsce. Zespół metaboliczny to zespół jednostek chorobowych, które w XXI wieku osiągają skalę światowej epidemii, stanowią także zwiększone ryzyko wystąpienia chorób sercowo-naczyniowych, które są główną przyczyną zgonów na świecie, co potwierdza jak znaczny problem zdrowotny stanowi nadciśnienie tętnicze, mimo obszernej wiedzy medycznej w tym zakresie.

W dostępnej literaturze medycznej istnieje niewiele publikacji naukowych dotyczących rozpowszechnienia diety DASH wśród pacjentów z nadciśnieniem tętniczym krwi. W grupie badanej $(n=50)$ żaden $\mathrm{z}$ respondentów nie stosował leczenia dietetycznego DASH, co więcej żadna $\mathrm{z}$ badanych osób nie wykazała znajomości tego rodzaju dietoterapii. Gajewska i wsp. uzyskali podobne wyniki oceniając znajomość i przestrzeganie zaleceń dietetycznych przez pacjentów z nadciśnieniem tętniczym krwi $(\mathrm{n}=86)$. W badaniu Gajewskiej i wsp. żaden z respondentów nie stosowal leczenia dietetycznego DASH, a tylko $15 \%$ badanych osób wskazywało na wprowadzenie jakiejś modyfikacji dietetycznej (12). Silaste i wsp. oceniając sposób żywienia pacjentów z nadciśnieniem tętniczym leczonych farmakologicznie $(n=716)$ nie uzyskali istotnych statystycznie różnic między sposobem żywienia osób badanych $\mathrm{z}$ nadciśnieniem tętniczym w porównaniu do grupy kontrolnej (osoby badane niechorujące na NT). Niemniej w obu grupach spożycie tłuszczów ogólnie, kwasów tłuszczowych nasyconych, węglowodanów i błonnika pokarmowego nie spełniało ogólnych zaleceń żywieniowych (13). Podobne wyniki uzyskano w projekcie WOBASZ II. Oceniając nawyki żywieniowe populacji polskiej powyżej 20. roku życia $(n=5690)$ w kontekście prewencji chorób sercowo -naczyniowych stwierdzono, że spożycie nasyconych i nienasyconych kwasów tłuszczowych oraz błonnika pokarmowego odbiega od wzorów racjonalnego żywienia. $\mathrm{W}$ tym projekcie naukowym zaobserwowano, że połowa badanej populacji nie spożywa zalecanej porcji warzyw i owoców (14). Girotto i wsp. $(n=385)$ oceniając przestrzeganie farmakologicznego i niefarmakologicznego leczenia NT zaobserwowali, że 59\% respondentów deklarowało stosowanie się do leczenia 
Girotto et al. ( $\mathrm{n}=385)$, while assessing the adherence to pharmacological and non-pharmacological treatment of $\mathrm{AH}$, observed that $59 \%$ of respondents declared compliance with pharmacological treatment, and $69 \%$ indicated changes in the diet to lower blood pressure (15).

Bednarski et al. assessing the nutritional knowledge and practical adherence of patients with arterial hypertension to the recommendations to limit table salt $(n=51)$ noted that $69 \%$ of respondents did not use any dietary treatment, and only $31 \%$ of the respondents declared using a low-sodium diet (16). In turn, Pudto et al. assessing the diet and eating habits of people with cardiovascular diseases (ischemic heart disease, arterial hypertension, lipid disorders, $n=193$ ) observed that in the group of patients with hypertension $(n=72)$ only 1/4 gave up salting food (17 ). Bronkowska et al., checking the nutritional knowledge of obese people with arterial hypertension $(n=52)$ noted that $66.7 \%$ of women and $87.1 \%$ of men did not use any dietary treatment. Interestingly, nearly $81 \%$ of respondents were aware that limiting table salt is used to prevent arterial hypertension (18). In the aforementioned WOBASZ II project $(n=5690)$ observed that $1 / 4$ of men and $1 / 5$ of women added table salt to already seasoned foods (14). In our study we noted that as many as $50 \%$ of patients with AH use salt twice a dayand $48 \%$ once a day. Only one respondent ( $2 \%$ ) declared that they did not use table salt.

Although the presented work covers a relatively small study group, to the research works of other authors, we found that the problem of obesity or metabolic disorders affects about half of patients with arterial hypertension. There is a need for research to assess the impact of dietary treatment on nutritional status and disorders metabolic in this group of patients in Poland.

\section{CONCLUSIONS}

1. Every second patient with arterial hypertension is obese and at the same time shows characteristics of the metabolic syndrome, which significantly increases the cardiovascular risk.

2. Patients with arterial hypertension do not follow the DASH dietary treatment, nor do they know the rules of this diet.

3. The diet of patients with arterial hypertension, both among patients with normal body weight and patients with overweight or obesity, differs from the dietary recommendations of a rational diet.

4. There is a need to educate patients with arterial hypertension in the field of non-pharmacological treatment methods, especially dietotherapy. farmakologicznego, a $69 \%$ wskazywało na zmiany w diecie celem obniżenia ciśnienia tętniczego krwi (15).

Bednarski $i$ wsp. oceniając wiedzę żywieniową i praktyczne stosowanie się pacjentów z nadciśnieniem tętniczym do zaleceń ograniczenia soli kuchennej $(n=51)$ odnotowali, że aż 69\% respondentów nie stosowało żadnego leczenia dietetycznego, a tylko $31 \%$ osób badanych deklarowało stosowanie diety niskosodowej (16). Z kolei Pudto i wsp. oceniając sposób żywienia i nawyki żywieniowe osób ze schorzeniami układu krążenia (choroba niedokrwienna serca, nadciśnienie tętnicze, zaburzenia lipidowe, $n=193$ ) zaobserwowali, że w grupie pacjentów z NT $(n=72)$ tylko $1 / 4$ rezygnuje $z$ dosalania spożywanych potraw (17). Bronkowska i wsp. sprawdzając wiedzę żywieniową otyłych osób z nadciśnieniem tętniczym $(\mathrm{n}=52)$ odnotowali, że $66,7 \%$ kobiet i aż 87,1\% mężczyzn nie stosuje żadnego leczenia dietetycznego. Co ciekawe blisko $81 \%$ respondentów miało świadomość, że ograniczenie soli kuchennej stosuje się celem zapobiegania nadciśnieniu tętniczemu (18). We wcześniej wspomnianym projekcie WOBASZ II $(\mathrm{n}=5690)$ zaobserwowano, że $1 / 4$ mężczyzn i $1 / 5$ kobiet dodaje sól spożywczą do już przyprawionych potraw (14). Natomiast w badanej przez nas grupie aż 50\% pacjentów z NT wykorzystuje dwa razy dziennie sól kuchenną do przyprawiania posiłków, a 48\% wykonuje tę czynność raz dziennie. Tylko jedna osoba badana (2\%) deklarowała, że nie używa soli spożywczej.

Mimo, że przedstawiona praca uwzględnia stosunkowo małą grupę badaną, to w odniesieniu do prac badawczych innych autorów można stwierdzić, że problem otyłości czy zaburzeń metabolicznych dotyczy około połowy pacjentów z nadciśnieniem tętniczym. Istnieje potrzeba przeprowadzenia badań naukowych oceniających wpływ leczenia dietetycznego na stan odżywienia i zaburzenia metaboliczne $\mathrm{w}$ tej grupie pacjentów w Polsce.

\section{WNIOSKI}

1. Co drugi pacjent $\mathrm{z}$ nadciśnieniem tętniczym krwi choruje na otyłość, jednocześnie wykazuje cechy zespołu metabolicznego, co znacznie zwiększa ryzyko sercowo-naczyniowe.

2. Pacjenci $z$ nadciśnieniem tętniczym nie stosują leczenia dietetycznego DASH, ani nie wykazują znajomości zasad tej diety.

3. Sposób żywienia pacjentów z nadciśnieniem tętniczym zarówno wśród pacjentów z prawidłową masą ciała, jak i pacjentów $\mathrm{z}$ nadwagą lub otyłością odbiega od zaleceń dietetycznych racjonalnej diety. 


\section{REFERENCES}

1. Tykarski A, Narkiewicz K, Gaciong Z, et al. Zasady postępowania $\mathrm{w}$ nadciśnieniu tętniczym - 2015 rok. Nadciśnienie tętnicze w praktyce 2015:1(1):1-70.

2. Tykarski A, Filipiak KJ, Januszewicz A i in. Zasady postępowania $\mathrm{w}$ nadciśnieniu tętniczym - 2019 rok. Nadciśnienie tętnicze w praktyce 2019;5(1):1-86.

3. Murguia-Romeo M, Flores R, Molina R. The body mass index (BMI) as a public health tool to predict metabolic syndrome. Open Journal of Preventive Medicine 2012;2(2):59-66.

4. Pacholczyk M, Ferenc T, Kowalski J. Zespół metaboliczny. Część I: Definicje i kryteria rozpoznawania zespołu metabolicznego. Epidemiologia oraz związek z ryzykiem chorób sercowo-naczyniowych i cukrzycy typu 2. Postępy Hig Med Dosw 2008;62:530-542.

5. Kucharska A, Burakowska I, Wronka L i in. Skład ciała a profil lipidowy chorych na nadciśnienie tętnicze. Pielęg Pol 2016;1(59):61-65.

6. Skop A, Kolarzyk E. Ocena sposobu żywienia i stanu zdrowia starszych mieszkańców domów pomocy społecznej. Now Lek 2005;74(4):480-483.

7. Jarosz M, Wolańska D, Stolińska H i in. Nutrition and lifestyle in patients pharmacologically treated due to hypertension. Cardiol J 2016;23(5):491-496.

8. Regulska-Ilow B, Mandecka A, Ilow R i in. Prevalence of diet atherogenicity and coexistence of lipid disorders and arterial hypertension among 50-year-old inhabitants of Wroclaw, Poland. Cent Eur J Public Health 2017;25(1):15-2.

9. Janssen I, Katzmarzyk PT, Ross R. Body mass index, waist circumference and health risk: evidence in support of current National Institutes of Health guidelines. Arch Intern Med 2002;162:2074-2079.

10. Skop-Lewandowska A, Ostachowska-Gąsior A. Stan odżywienia osób z rozpoznanymi chorobami układu sercowo-naczyniowego. Probl Hig Epidemiol 2009;90(4):604-607.

11. Lakowska A, Chrostowska M, Szyndler A i in. Rozpowszechnienie zespołu metabolicznego u chorych z nadciśnieniem tętniczym w zależności od płci. Arterial Hypertension 2005;9(6):458-462.

12. Gajewska D, Ździeborska M, Harton A i in. Ocena znajomości i przestrzegania zaleceń dietetycznych przez pacjentów z nadciśnieniem tętniczym pierwotnym. Probl Hig Epidemiol 2013;94(2):258-261.
4. Istnieje potrzeba edukacji pacjentów $\mathrm{z}$ nadciśnieniem tętniczym krwi w zakresie niefarmakologicznych metod leczenia, w tym szczególnie dietoterapii.

13. Silaste ML, Junes R, Rantala AO i in. Dietary and other non-pharmacological treatments in patients with drug-treated hypertension and control subjects. J Intern Med 2000;247(3):318-324.

14. Waśkiewicz A, Szcześniewska D, SzostakWęgierek D i in. Are dietary habits of the Polish population consistent with the recommendations for prevention of cardiovascular disease? WOBASZ II project. Kardiol Pol 2016;74(9):969977.

15. Girotto E, de Andrade SM, Cabrera MA $i$ in. Adherence to pharmacological and non pharmacological treatment for arterial hypertension and associated factors in primary care 2013;18(6):1763-1772.

16. Bednarski A, Czakon A, Stolarz-Skrzypek K i in. Wiedza żywieniowa i praktyczne stosowanie się pacjentów z nadciśnieniem tętniczym do zaleceń ograniczenia spożycia soli kuchennej. Arterial Hypertension 2013;17(6):422-429.

17. Pudło H, Respondek M. Sposób żywienia i nawyki żywieniowe osób ze schorzeniami układu krążenia. Pielęg Pol 2014;3(53):191-197.

18. Bronkowska M, Martynowicz H, Żmich $\mathrm{K}$ i in. Zwyczaje żywieniowe otyłych osób $\mathrm{z}$ rozpoznanym nadciśnieniem tętniczym. Roczn PZH 2010;61(1):75-81.

Received: 19.06.2020

Accepted for publication: 12.02.2021

Otrzymano: 19.06.2020 r.

Zaakceptowano do publikacji: : 12.02.2021 r.

\section{Address for correspondence: \\ Adres do korespondencji:}

Alina Niezgódka-Klósak,

Uniwersytet Medyczny im. Karola Marcinkowskiego w Poznaniu-

Katedra i Klinika Gastroenterologii, Dietetyki i Chorób Wewnętrznych, ul. Przybyszewskiego 49, 60-355 Poznań email:niezgodkaalina@gmail.com 